\title{
Evaluasi Kandungan Nutrien Bungkil Wijen Lokal Sebagai Bahan Pakan Unggas
}

\author{
I. Astuti \\ Jurusan Peternakan, Fakultas Pertanian, Universitas Sebelas Maret \\ Jl. Ir. Sutami 36 A, Kentingan, Surakarta
}

\section{INTISARI}

Penelitian ini bertujuan untuk mengetahui kandungan nutrien bungkil wijen lokal sebagai bahan pakan unggas, digunakan tiga varietas biji wijen yaitu Lokal Hitam, S1 dan S2. Biji wijen diperoleh dari Kecamatan Bendosari, Kabupaten Sukoharjo, Jawa Tengah. Pengamatan dilakukan melalui analisis proksimat di laboratorium Nutrisi dan Makanan Ternak, Jurusan Peternakan, Fakultas Pertanian Universitas Sebelas Maret. Hasil yang diperoleh menunjukkan bahwa rendemen bungkil berkisar antara 61,48 sampai 63,50\% dari bobot biji. Kandungan nutrien varietas Lokal Hitam adalah 40,13\% protein kasar (PK), 20,08\% lemak kasar (LK), 4,68\% serat kasar (SK), 10,17\% abu dan $3212 \mathrm{kkal} / \mathrm{kg}$ ME. Kandungan nutrien varietas S1 adalah 37,91\% PK, 19,12\% LK, 6,01\% SK, 9,52\% abu dan $3113 \mathrm{kkal} / \mathrm{kg} \mathrm{ME}$, sementara varietas S2 mengandung nutrien 39,58\% PK, 26,26\% LK, 6,21\% SK, 7,85\% abu dan $3195 \mathrm{kkal} / \mathrm{kg}$ ME. Secara umum disimpulkan bahwa bungkil wijen lokal dapat digolongkan sebagai bahan pakan sumber protein.

Kata kunci : bungkil wijen lokal, kandungan nutrien

\section{Evaluation Nutrient Contents of Local Sesame Meal as Feedstuff of Poultry}

\begin{abstract}
The present study was conducted to evaluate nutrient contents of local sesame meal as feedstuff of poultry. Three varieties of sesame seed were investigated, there were Local Black, S1 and S2. Its founded from Bendosari district, Sukoharjo regency, Central of Java Province. The experimant was done throught proximate analyses in the laboratory of Feed and Animal Nutrition, Departement of Animal Husbandry, Agricultural Faculty, Sebelas Maret University. The result showed that amount of sesame meal between 61,48 to 63,50\% from weight of seed. Nutrient composition of Local Black sesame meal was 40,13\% crude protein (CP), 20,08\% crude fat, 4,64\% crude fiber, 10,17\% ash and $3212 \mathrm{kcal} / \mathrm{kg} \mathrm{ME}$. Nutrient composition of S1 sesame meal was 37,91\% CP, 19,12\% crude fat, 6,01\% crude fiber, 9,52\% ash, $3113 \mathrm{kcal} / \mathrm{kg} \mathrm{ME}$ whereas nutrient composition of $\mathrm{S} 2$ was $39,58 \% \mathrm{CP}$, $26,26 \%$ crude fat, $6,21 \%$ crude fiber, $7,85 \%$ ash and $3195 \mathrm{Kcal} / \mathrm{kg} \mathrm{ME}$. The result of this experiment concluded that local sesame meal is generally good as feedstuff protein source in terms of chemical composition based 'proximate analyses' especially CP content.
\end{abstract}

Key words : local sesame meal, nutrient contents 


\section{PENDAHULUAN}

Usaha peternakan ayam broiler selalu dihadapkan dengan tiga faktor penunjang keberhasilan yaitu bibit, pakan dan manajemen yang ketiganya saling berkaitan. Faktor pakan mempunyai peran sebesar $30 \%$ dalam menentukan keberhasilan usaha dengan menyerap biaya produksi yang paling tinggi yaitu berkisar antara 60 sampai 80\% (Scanes et al., 1992; Rasyaf, 1994)

Harga ransum ayam broiler semakin lama semakin mahal. Hal ini disebabkan sebagian bahan pakan penyusun ransum masih bergantung dari impor terutama tepung ikan dan bungkil kedelai. Bungkil kedelai hampir selalu digunakan dalam formula ransum broiler dan banyaknya dapat mencapai $30 \%$ dari total ransum. Kandungan proteinnya yang tinggi dengan asam amino yang seimbang kecuali metionin telah menempatkan bungkil kedelai sebagai bahan pakan sumber protein yang handal sehingga meningkatnya harga bungkil kedelai tentu akan sangat berpengaruh pada meningkatnya harga ransum. Sebagai solusi dari kesulitan ini perlu diusahakan pemanfaatan bahan pakan lain yang setara kualitas nutriennya dengan bungkil kedelai, mudah tersedia, murah serta aman bagi kesehatan.

Salah satu hasil samping industri yang belum banyak dimanfaatkan sebagai bahan pakan adalah bungkil wijen. Di daerah Kabupaten Sukoharjo, Jawa Tengah, terdapat beberapa daerah produsen wijen. Pada pengolahan biji wijen menjadi minyak diperoleh hasil samping berupa bungkil. Pada awalnya bungkil ini diolah lebih lanjut menjadi pangan tradisional yang disebut "cabuk". Namun karena konsumennya yang semakin berkurang serta adanya upaya peningkatan pengolahan minyak wijen, maka dihasilkan bungkil yang cukup banyak.

Bungkil wijen mengandung nutrien yang tinggi, menurut Ketaren (1986) per $100 \mathrm{~g}$ biji wijen berkulit mengandung PK 18,60 g, LK 49,10 g, karbohidrat 21,60 g, air 5,40 g, SK 6,30 g dan abu 5,30 g.
Ditambahkan oleh Poulence (1993), bungkil wijen memiliki kandungan PK 45\%, LK $1 \%$, SK $7 \%$, abu $14 \%$ dan ekstrak tanpa nitrogen $23 \%$. Oleh karena itu, di negara penghasil wijen seperti India, Irak, Mesir, Pakistan, Thailand dan China, bungkil wijen telah lazim digunakan sebagai bahan formula ransum (Daghir, 1995).

Kandungan nutrien suatu bahan pakan dipengaruhi oleh beberapa faktor seperti varietas, tanah, iklim maupun cara pengolahan. Nilai nutrien bahan pakan unggas setidaknya mencerminkan nilai $\mathrm{PK}$, LK, SK, dan abu yang mana nilai tersebut dapat diketahui melalui hasil analisa proksimat di laboratorium.

Tujuan dari penelitian ini adalah untuk mengevaluasi kandungan nutrien dari bungkil wijen lokal dan diharapkan dapat dipergunakan sebagai bahan pakan alternatif pengganti bungkil kedelai. Hasil penelitian ini diharapkan dapat membri informasi tentang potensi nutrien bungkil wijen sebagai bahan formulasi ransum khususnya untuk ternak unggas.

\section{MATERI DAN METODE}

Penelitian ini merupakan uji kimia yang dilakukan di Laboratorium Nutrisi dan Makanan Ternak Jurusan Peternakan Fakultas Pertanian Universitas Sebelas Maret untuk analisa proksimat dan Pusat Studi Pangan dan Gizi Universitas Gadjah Mada untuk penentuan Gross Energi.

Contoh (sampel) yang digunakan berasal dari tiga varietas biji wijen yaitu varietas Hitam lokal, varietas Sambirejo 1 (S1) dan Sambirejo 2 (S2), yang diperoleh dari Kecamatan Bendosari Kabupaten Sukoharjo, Jawa Tengah. Bahan kimia yang digunakan meliputi $\mathrm{H}_{2} \mathrm{SO}_{4}$ pekat, katalis Kjeldhal, Na- tiosulfat, natrium hidroksida, asam borat $4 \%$, indikator mix, HCL $0,02 \mathrm{~N}$, petrolium ether, $\mathrm{H}_{2} \mathrm{SO}_{4} 1,25 \%, \quad \mathrm{NaOH}$ $3,25 \%, \mathrm{~K}_{2} \mathrm{SO}_{4} 10 \%$ dan aseton.

Pelaksanaan penelitian dilakukan dalam dua tahap yaitu pembuatan bungkil wijen sebagai contoh (sampel) dan analisa kimia. Data diolah pengolahan data secara 
diskriptif. Penyiapan contoh dilakukan dengan mengekstraksi minyak dari biji wijen secara mekanik untuk menghasilkan bungkil yang selanjutnya disiapkan sebagai contoh. Analisis contoh mencakup analisis proksimat dan penentuan gross energi. Analisis proksimat meliputi kadar air, kadar abu, LK, PK dan SK yang dilakukan menurut metode Weende dalam Muchtadi dan Sugiyono (1992), sedangkan penentuan Gross Energi dilakukan dengan Bomb Kalorimeter.

\section{Preparasi Bungkil Wijen}

Dalam penelitian ini bungkil wijen sengaja dipersiapkan sendiri di laboratorium dan tidak diambil dari bungkil yang diproduksi oleh home industry minyak wijen dengan maksud untuk menjaga homogenitas varietas biji wijen yang digunakan.

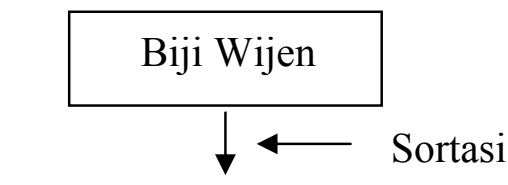

Jemur sampai kering

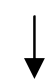

Tambahkan sedikit air panas $\pm 90^{\circ} \mathrm{C}$

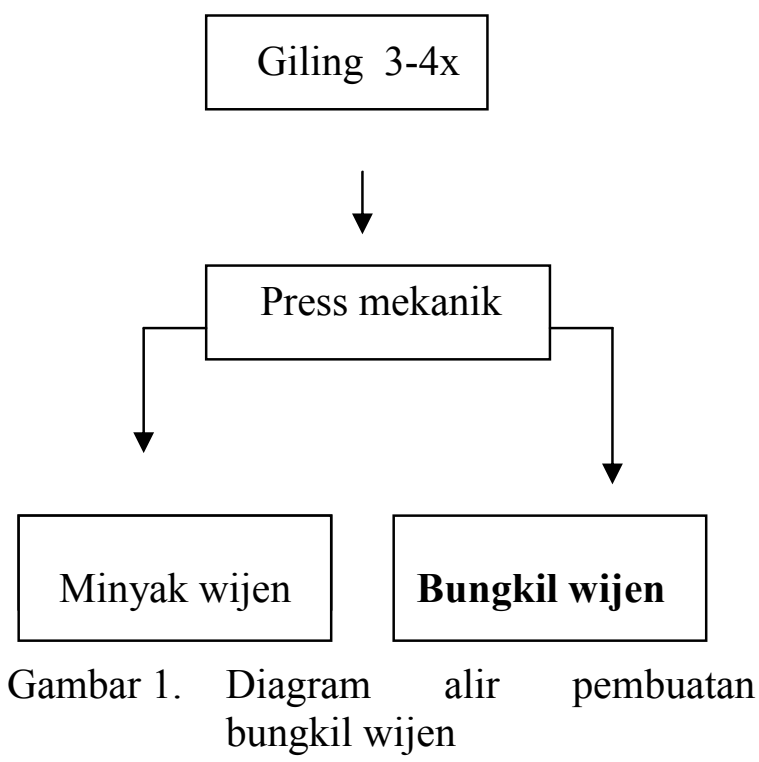

Mula-mula biji wijen disortir dari berbagai kotoran (sisa kulit, daun, batang dan kotoran lain), kemudian dijemur kering. Setelah kering digiling dengan mesin penggiling daging untuk memecah/ mencincang biji wijen. Penggilingan dilakukan tiga sampai empat kali sambil ditambah sedikit air panas agar biji agak lembab dan mudah hancur. Setelah cukup halus selanjutnya diperas dengan press mekanik untuk mengeluarkan/ memeras minyaknya. Residu yang diperoleh berupa padatan yang disebut bungkil seperti disajikan pada Gambar 1. Selanjutnya bungkil dihaluskan, dihomogenkan dan disiapkan sebagai contoh analisa.

\section{Metode Analisis}

Bungkil wijen yang diperoleh dari hasil ekstraksi minyak, selanjutnya digiling halus dan homogen, disimpan dalam tempat kering dan siap untuk dianalisa. Nilai nutrien yang diamati dalam penelitian ini adalah kadar air, abu, PL, LK dan SK. Metode analisis dikerjakan menurut Muchtadi dan Sugiyono (1992)

\section{HASIL DAN PEMBAHASAN}

\section{Rendemen Bungkil Wijen}

Wijen (Sesamun indicum) termasuk familia Pedaliaceae merupakan golongan cerealia. Kandungan minyaknya yang tinggi merupakan keunggulan sehingga biji wijen sering diekstrak minyaknya. Minyak wijen bernilai ekonomi tinggi dan banyak digunakan sebagai pangan, penambah taste, kosmetik maupun indistri farmasi. Dari ekstraksi tersubut akan diperoleh hasil samping berupa bungkil. Ditinjau dari penampilan fisiknya, biji wijen varietas Hitam lokal mempunyai kulit biji berwarna hitam dan kecil, biji wijen S1 berwarna coklat tua dan biji wijen S2 berwarna coklat muda. Varietas S1 dan S2 mempunyai ukuran biji yang lebih besar dari pada varietas Hitam. Dalam Tabel 1 
disajikan hasil rendemen bungkil dari ketiga varietas biji tersebut.

Tabel 1. Hasil Rendemen Bungkil Wijen Pada Berbagai Varietas Lokal (\% Bobot Biji)

\begin{tabular}{lc}
\hline \hline \multicolumn{1}{c}{ Varietas } & $\begin{array}{c}\text { Rerata Rendemen } \\
(\%)\end{array}$ \\
\hline Hitam & 61,48 \\
Sambirejo 1 (S1) & 63,46 \\
Sambirejo 2( S2) & 63,50 \\
\hline
\end{tabular}

Dalam penelitian ini, pengamatan dilakukan sebanyak tiga kali untuk masingmasing varietas. Secara umum dapat diketahui bahwa dari ketiga varietas tersebut dalam pengolahan menjadi minyak wijen, menghasilkan rendemen bungkil yang hampir sama jumlahnya yaitu $61,48 \%$ untuk varietas Hitam lokal, 63,46\% untuk varietas S1 dan $63,50 \%$ untuk varietas S2.

Sebelum bungkil wijen ini disimpan sebagai cadangan pakan harus dijemur kering terlebih dahulu karena berdasarkan pengamatan selama penelitian bungkil wijen yang tidak kering mudah ditumbuhi jamur dan berbau rancid (tengik). Diduga hal ini disebabkan dalam proses pengolahan ditambahkan sedikit air panas pada biji sebelum digiling, kemudian dipress sehingga diperoleh bungkil yang padat dan keras. Hal ini menyebabkan sebagian air terperangkap di dalam bungkil, menimbulkan kelembaban dan tidak segera kering sehingga memicu tumbuhnya jamur dan hidrolisis minyak/ lemak (Colby, 1996). Bau rancid timbul karena terjadinya hidrolisis asam lemak oleh ensim yang menghasilkan senyawa keton dan aldehid ( Donald et a1. 2002).

\section{Kandungan Nutrien}

Berdasarkan hasil analisis proksimat diketahui kandungan nutrien bungkil wijen meliputi kadar air, PK, LK, SK dan abu seperti tertera pada Tabel 2.

Dari hasil analisa tersebut diketahui bahwa bungkil wijen dari ketiga varietas tersebut mengandung protein kasar 40,13\% (Hitam), 37,91\% (S1) dan 39,58\% (S2). Pada umumnya bahan pakan biji-bijian yang mengandung protein tinggi adalah berasal dari Leguminaceae, tetapi dalam hal ini bungkil wijen yang sebenarnya bukan golongan Leguminaceae ternyata mengandung protein kasar cukup tinggi dan bahkan setara dengan bungkil kedelai.

Tabel 2. Kandungan nutrien bungkil wijen berbagai varietas lokal (\%)

\begin{tabular}{|c|c|c|c|}
\hline \multirow{2}{*}{$\begin{array}{c}\text { Jns Nutrien } \\
(\%)\end{array}$} & \multicolumn{3}{|c|}{ Varietas } \\
\hline & Hitam & S1 & $\mathrm{S} 2$ \\
\hline Air & 6,80 & 7,40 & 8,80 \\
\hline $\mathrm{Abu}$ & 10,17 & 9,52 & 7,85 \\
\hline PK & 40,13 & 37,91 & 39,58 \\
\hline LK & 20,08 & 19,12 & 26,26 \\
\hline SK & 4,64 & 6,01 & 6,21 \\
\hline $\begin{array}{l}\text { GE } \\
(\mathrm{kkal} / \mathrm{kg})\end{array}$ & 4015 & 3891 & 3993 \\
\hline $\begin{array}{l}\mathrm{ME} \\
(\mathrm{kkal} / \mathrm{kg})^{1}\end{array}$ & 3212 & 3113 & 3195 \\
\hline
\end{tabular}
(Sibbald, 1980)

Menurut Tillman et al. (1982) bahwa bahan pakan yang mengandung protein lebih dari 20\% dengan SK kurang dari 18\% dapat digolongkan sebagai bahan pakan sumber protein. Menurut Lesson dan Summer (2005), bungkil wijen juga merupakan sumber asam amino metionin, sistein dan triptofan, namun defisien pada asam amino lisin. Oleh karena itu, penggunaannya dalam ransum terutama untuk ternak monogastrik perlu dikombinasikan dengan bahan pakan yang kaya lisin, misalnya tepung ikan atau disuplementasi dengan asam amino sintetis. Melalui teknik suplememtasi tersebut, bungkil wijen dapat menggantikan 50\% penggunanaan bungkil kedelai (Daghir ,1995; Wahyu 1992).

Kandungan lemak pada bungkil wijen pada penelitian ini terlihat cukup tinggi yaitu 20,08\% (Hitam lokal ), 19,12\% (S1) dan 26,26\% (S2). Bungkil wijen dari negara luar yang diproses dengan ekstraksi solven kandungan lemaknya kurang dari $3 \%$. 
Adanya lemak yang tinggi pada bungkil wijen lokal ini diduga disebabkan karena proses pembuatannya yang sederhana sehingga ekstraksi minyak kurang sempurna. Dengan demikian nilai energinya juga cukup tinggi. Nilai Gross Energy (GE) berkisar antar 3891 - $4016 \mathrm{kkal} / \mathrm{kg}$ dan nilai Metabolized Energi (ME) berkisar antara 3113 - $3212 \mathrm{kkal} / \mathrm{kg}$. Minyak wijen kaya akan asam lemak tak jenuh, menurut Katzer (1999) minyak wijen mengandung asam oleat $35,50 \%$, asam linoleat $35-50 \%$ dan asam linolenat $\leq 1 \%$ sehingga hal ini merupakan nilai lebih dari bungkil wijen lokal dibanding bungkil sumber protein lainnya.

\section{KESIMPULAN}

Bungkil wijen lokal, hasil samping home industry pengolahan minyak wijen di daerah Sukoharjo mempunyai potensi nutrien yang cukup baik sebagai bahan pakan. Berdasarkan kandungan protein, bungkil wijen lokal dapat dipergunakan sebagai bahan pakan sumber protein dan diharapkan dapat mensubstitusi sebagian penggunaan bungkil kedelai. Jumlah bungkil yang diperoleh berkisar antara $60 \%$ dari berat biji yang diproses.

\section{DAFTAR PUSTAKA}

Colby, S.D., 1996. Ringkasan Biokimia Harper. Alih bahasa Adji Dharma. Penerbit EGC., Jakarta

Daghir, N.J. 1995. Feedstuff Used in Hot Region. In Poultry Production in Hot
Climates. CAB International UK, Cambridge.

Donald, Mc. J..F.D. Greenhalgh dan C.A.Morgan. 2002. Animal Nutrition. $6^{\text {th }}$ Ed. Prentice Hall, New York.

Katzer, G. 1999. Toasted Sesame Oil (treabdxngmre), modification date Dec, 17, 1999.

Ketaren, S. 1986. Minyak dan Lemak Pangan. UI Press, Jakarta.

Lesson, S. dan J.D. Summer. 2005. Commercial Poultry Nutrition. 3th. Departement of Animal and Poultry Science University of Guelph. Ontario, Canada.

Muchtadi dan Sugiyono, 1992. Ilmu Pengetahuan Bahan Pangan. Depdikbud. Dirjen Dikti. PAU Pangan Gizi IPB, Bogor.

Rasyaf, M.1990. Bahan Makanan Unggas di Indonesia. Kanisius. Yogyakarta.

Poulence, R. 1993. Animal Nutrition. Rhodimet Feed Formulation Guide. $6^{\text {th }}$.

Scanes, C.G., G. Brant dan M.E. Ensminger. 1992. Poultry Sciense. Fourth Ed. Upper Saddle River, New Yersey.

Sibbald, I.R. 1980. The Effect of Level Feed Intke on Metabolized Energy Value with adult roasters. Poultry Sci. 54:130-145

Tillman, A.D., S. Reksohadiprodjo, S. Prawirokusumo dan S. Lebdosoekojo. 1992. Ilmu Makanan Ternak Dasar. Gadjah Mada University Press, Yogyakarta. 